\title{
Research on Chinese Traditional Design Elements and Modern Environmental Art Design
}

\author{
Fei Xiong \\ Wuchang Institute of Technology, Wuhan, Hubei, 430065
}

Keywords: Chinese Traditional Design Elements, Modern Environment, Art Design

\begin{abstract}
Chinese traditional cultural elements in the modern environmental art design is of great significance. In the design of modern environmental art, designers should pay attention to the clever application of traditional cultural elements, and establish innovative consciousness, design rich traditional Chinese characteristics and meet the modern aesthetic psychology of environmental art design works to promote the national culture inheritance and development, also Promote the development of modern environmental art design. This paper mainly discusses the role and application of Chinese traditional cultural elements in the design of modern environmental art with the connotation of traditional Chinese cultural elements and modern environmental art design.
\end{abstract}

\section{Introduction}

Chinese traditional cultural elements are clever use of architecture, clothing, music and other aspects of the prominent traditional cultural spirit of the image composition, as well as highlight the national characteristics of the symbols, customs and image. In addition to the traditional Confucianism, Taoism and other ideology embodies the essence of the nation's cultural elements. Modern environmental art design is the environmental connotation and design concept of organic integration of the expression of the art form, is also a comprehensive application of disciplines. Environmental art design works emphasizes the integration of artistic ideas and the environment, and through the light and shadow color, spatial shape and other modeling language presented to strengthen the environment-based modern art design concept, to better demonstrate different forms of art. Like modern works, outdoor design, landscape garden, urban planning are typical of modern environmental art design.

\section{The Connotation of Chinese Traditional Cultural Elements and Environmental Art Design}

China is a cultural ancient country, deep cultural heritage. Chinese traditional cultural elements, refers to the use of architecture, clothing, painting and the like on some of the image, embodies the traditional Chinese culture, and reflects the national dignity and national interests of the image, symbols or customs, all belong to the traditional Chinese cultural elements The Our country stresses the unity of opposites, the moderation of Confucianism and pay attention to inaction of Taoism, belong to the scope of traditional Chinese cultural elements.

Environmental art design is an emerging comprehensive discipline, is based on the environment and the existence of an art form, the work emphasizes the environment and dependency, integration of relations, emphasizing the expression of the artist's artistic concept, material texture, spatial size, light color, Scale and other modeling language performance, so that works into the atmosphere of the environment. Including interior decoration, interior and exterior design, decoration design, landscape garden, landscape sketch (scene sculpture, green, road), architectural decoration and decoration, urban planning and so on. 


\section{The Role of Chinese Traditional Cultural Elements in Contemporary Environmental Art Design}

Modern environmental art designers to establish into the national traditional culture of the creative concept, in the process of environmental art design, with the help of modern design means, the effective integration of traditional features, regional characteristics and national characteristics for all local folk customs and cultural characteristics, To create environmental art development space, to give environmental art design works lasting vitality and vitality, with the formation of Chinese characteristics of the environmental art design creation model, and promote China's environmental art design business sustainable development.

China's traditional culture in the "expensive", that is, China's traditional culture is implicit, words are endless and endless. Environmental art is both a form of language, but also emotional language, both concrete and abstract, both determined and uncertain. Therefore, the environmental art design should be moving in the environment, avoid the art language too much, too intuitive, let people have a lot of association and often memorable, have different feelings and different mood, to play for everyone to create opportunities for imagination, The implication of traditional culture lies.

China's traditional culture, such as "harmony between man and nature", "the actual situation and so on" and other concepts, contains sustainable development, harmonious development and scientific development of the idea, emphasizing the environment and people to adapt to nature, harmony with nature, The realm of one. China's deteriorating ecological environment to alert the designers to change the design ideas, to the traditional Chinese culture as the concept, learn from its inherent essence, combined with Western modern design concept, designed with traditional cultural heritage and modern design style of environmental art Design work, to achieve sustainable development, the benefit of mankind.

In the context of cultural development and integration, take the essence of national culture, and learn from other countries of outstanding culture, in the world cultural development occupies a certain position. And the environmental art design works is an important manifestation of national culture, the relationship between the development of national culture, the traditional Chinese cultural elements also involves the essence of national culture, so designers into the traditional cultural elements, tap the essence, make works of art more prominent national Characteristics, and full of vitality.

China's traditional cultural elements reflect the characteristics of the implicit beauty, the traditional Confucianism also stressed the pursuit of subtle beauty. Will be rich in the traditional elements of the United States for the environmental art design can enhance the connotation of the work to create a reverie space, careful meticulous experience to feel the works contained in the mood, while inspiring imagination, in the subtle beauty linger. This is the essence of implicit beauty.

Modern environmental art works mainly by the traditional and modern cultural elements of the integrated design, the designer needs to integrate all kinds of elements to play the appeal of the work. Environmental issues have always been a matter of concern to people, so environmental art designers to establish a natural combination of design concepts, combined with traditional cultural elements such as "harmony between man and nature" concept and excellent design theory of the essence of art design, more able to enhance the art The appeal of the work.

In the case of

\section{The Application of Chinese Traditional Cultural Elements in Modern Environmental Art Design}

China's ancient architecture, garden art is a shining pearl in the world's architectural treasures, all kinds of palaces, altar temples, temples, pagodas, houses and garden art embodies the unique artistic charm of Chinese ancient architecture, bringing endless The visual aesthetic enjoyment, is an important source of inspiration for the design of modern environmental art, the use of appropriate 
methods, so that the integration of traditional Chinese cultural elements of modern environmental art reproduction of colorful,

In the modern environmental art design, the traditional culture of some of the symbolic visual form, penetrate into the modern environmental art design, to create a new visual form, to express a new interest, emotion and thought. Or the innovation of traditional cultural elements, so that both the traditional cultural elements of the shape and charm, but also has a modern environmental art design means and form, reflecting a nation's temperament, spirit and philosophy. In the modern environmental art design, can also be applied directly to many traditional graphics, the traditional cultural elements placed on a new carrier, showing a new visual language environment, so that the original graphics information to be more meaningful play, Fully embodies the designer's creativity and the expression of traditional cultural elements.

At present, in the design of environmental art, the method of extracting, transforming and abstracting the traditional cultural elements is widely used. The designers capture and discover the elements of beauty in the rich traditional cultural elements, and then extract the applicable elements as the creative material , And the transformation and abstraction of these original materials, according to the design of the image composition, the use of modern design concepts and aesthetic taste, the traditional Chinese culture and art reconstruction, re-interpretation and explore the essence of traditional culture, to find the combination of Eastern and Western cultures Point, the formation of a traditional cultural atmosphere of modern environmental art design works. 1998 built in Shanghai Economic and Trade Building, is a traditional cultural elements of the extraction, transformation, processing of typical cases. Designers will be classical "tower" structure, applied to a modern skyscraper architectural design, the designer is not rigid amplification tower, but from the perspective of mechanics and aesthetics, the proportion of Chinese tower aesthetics and the proportion of the entire building phase Anastomosis. Architectural designers will be the traditional Chinese Miyan tower as the design of the origin of the design, highly summarized Miyan tower rhythm, contour lines and details, the traditional building of the spiritual image, through the modern design concept and construction means perfect.

Metaphor is a modern environmental art design of a way, that is, through a certain element of environmental composition and composition to express the spirit of the environment outside the body, such as cultural connotation, meaning, value orientation and other high level of cultural information. In the ancient Chinese architecture and interior decoration art, the choice of cultural patterns and furnishings, are reflected in the more profound cultural connotations, are implicit expression of people want to express the emotions. In today's social conditions, the innovation of traditional cultural elements is the work of our modern environmental art design, must be modern, but also China, in a region, should also reflect the region's national characteristics and cultural characteristics, which Is full of local flavor of the flesh and blood of good works. $\mathrm{Mr}$. Wu Liangyong designed the Qufu Confucius Institute complex, which is a successful example of metaphor and innovation of traditional cultural elements. Confucius Institute of the garden design using the ancient "College" approach, the idea of sophisticated, rigorous layout. In the design, in the north of the building pile of soil, a symbol of mountains, the south of the earth, the symbol of the mountain, the building group designed to build a diversion canal, metaphor Qinglong, building a positive design built a small Yi River, metaphor Feng Shui in the " Surrounded by gold, "the whole layout reflects the traditional cultural concept and the traditional feng shui said that the location of the building group negative Yin Yang, in front of the case, the back of the mountain. To a variety of traditional architectural elements as a design prototype, the full use of metaphor techniques, in accordance with the modern aesthetic concept of refining, variation, interpretation of the reconstruction, after all, the metaphor of traditional cultural elements and innovative classic.

The development of modern environmental art design is inseparable from innovation. The designer can apply the appropriate elements from the traditional cultural elements to the design, but also requires the designer to dare to try, be active and be creative, so as to give new expressions of traditional cultural elements. Such as the design of Shanghai Economic and Trade Building, the designer combined with the traditional "tower" structure into the modern design, summed up the 
characteristics of the tower structure, and the tower eaves overlapping order, the overall magnificent, which involves the elements of innovation, The integration of traditional elements under the tower elements and modern design in mechanics, aesthetics and other angles do not conflict, and presents the innovative characteristics of the harmonious beauty. Innovation of traditional cultural elements is an important source and motive force for the development of modern environmental art design. Designers should establish a sense of innovation, the traditional cultural elements involved in the innovative factors into the modern design, giving a new visual impact effect, to create rich historical and cultural characteristics of modern innovative works. This not only demonstrates the essence of traditional culture, but also adhering to the spirit of innovation, and art forms are presented, to better promote the development of modern environmental art design, promote the traditional Chinese culture, to achieve the practical significance of modern environmental art design

\section{Conclusion}

The combination of traditional cultural elements and modern environmental art design and the innovation of traditional cultural elements are important channels to reflect the essence of traditional culture. The designers need to establish the creative consciousness, play creative thinking, based on the modern environment of traditional cultural elements of the selection and transformation, innovation, design rich traditional Chinese characteristics and in line with modern aesthetic psychology of environmental art design works to promote the national culture inheritance and development, But also to promote the development of modern environmental art design.

\section{References}

[1] Ma Yushan. Jing family characteristics in the Nixing pottery decoration design [J]. China Ceramics. 2015 (06)

[2] Zhang Shiyue. Regional elements in the Korean public design performance [J]. Decorative. 2015 (06)

[3] Pan Zhaixia. Application of traditional elements in modern forming knitted garment design [J]. Knitting Industry. 2014 (09)

[4] Cao Jun. The Application of Xiangxiu Acupuncture Elements in the Design of Hunan Tourist Souvenirs - An Analysis of the Design Scheme of "Xiang Xiang Guan Xiang Taiwan Calendar" [J].

[5] Chen Huishu. Chinese traditional elements in the modern graphic design of the significance [J]. Art observation. 2013 (05)

[6] Wang Lixin, Fan Xuelong. Fashion leather products design theme elements and performance [J]. China Leather. 2012 (08) 